\title{
Musical Experience in Deaf Culture
}

\author{
Tatiane Ribeiro Morais de Paula, Patrícia Lima Martins Pederiva \\ University of Brasília, Brazil
}

\begin{abstract}
This work is based on a dissertation in progress aiming to investigate possibilities of musical education for the development of musicality of the deaf people, considering their culture. The representation of music in contemporary society carries with it traces of its design based on a series of ideas and ideals that include a music to be heard, being this one of the numerous possibilities this individual has to perceive it. Considering the individual as an intellect-affect unit, based on the historical-cultural perspective of Vygotsky, we have as a source of research to understand this individual in his entirety and, therefore, to perceive him in the wholeness and interaction of his senses. Here we seek to understand these possibilities by means of sensory ethnography, which considers the interconnectivity of the senses in the individual, arguing that they are not disjoined, but interconnected.
\end{abstract}

\section{Introduction}

In Brazil, basic, compulsory and free education, from four to seventeen years old, is organized as follows: (1) pre-school (four and five years old); (2) elementary school (six years old to fourteen years old) and (3) secondary education (fifteen years old to seventeen years old). This structure is governed by the Law of Directives and Bases of National Education - LDB - No. 9394 of December 1996. In 2008, with the Law No. 11,769 of August 18, it was established the obligation of teaching music in basic education.

Faced with such obligation, we were concerned about what this music education would be like for deaf children. In addition, there was a need for understanding how the deaf person experiences his musicality, such as his experience with the sound universe that encompasses not only sound as a whole, but its elements: the frequency, the vibration, timbre, rhythm, amplitude.

In this regard, I recall a few accounts of Helen Keller, the first deaf and blind person to earn a bachelor's degree, graduating in Philosophy at Radcliffe College. Keller was a writer, lecturer and an American social activist. She made her debut in literature by publishing her autobiography: The story of my life. Her story became widely known by means of both play "The Miracle Worker" and film "The Miracle of Anne Sullivan" (1962).

In Keller's reports, her identification with music as a source of pleasure and expression becomes evident. We must remember that, at any moment, her situation was difficult, and that the dedication of Keller's teacher was fundamental for her development.

Thinking in this context allows us to perceive that the school environment and society must open up to the changes that have taken place in education, as well. That is, those directly involved in this context have to appropriate, on a continuous basis, new learning, new methodologies and, in the case of musical education for the deaf, to discover, from them, ways for inclusion to be effective. "Inclusion means listening and responding to what the other person asks for in his own voice. As humans, it is not the language that speaks to us" (Illich as cited in Tunes \& Bartholo, p. 147) [1].

When it comes to education for deaf people, it is not possible to think of inclusion as it has been thought: The deaf student in regular education in which his (or her) culture and his (or her) language are unknown, being not possible a full relationship with all those involved in that school environment. In turn, this student is isolated in his (or her) condition, depending on the interpreter to communicate and to relate with his peers.

In our understanding, the afore mentioned condition does not characterize inclusion and not even an education based on diversity and difference. We understand that education must offer the same opportunities, in which the relation with the other is possible; in which the exchange of experience exists on the basis of "an education coexistencial and ethical" (Pederiva, personal communication, GEPPE- Group of Studies and Research in Educational Practice at the University of Brasilia, 2016).

When we think and talk about the word music, the representation that comes to our mind is linked to social representation of what has been produced, presented and offered to society actually. The songs are produced mostly in studios with professionals and institutionalized instruments, for music production created and thought having in mind a listener population. "Music, from ancient, has been created and designed for listeners" (Gonçalves, personal communication, GEPPE- Group of Studies 
and Research in Educational Practice at the University of Brasilia, 2016) and those who do not meet this norm, remain silent .

Similarly, we see how the musical question requires perfection or at least a natural gift of the individual to exercise his musicality. Pederiva and Tunes capture this connundrum by saying: "The musical expression becomes rulled by the technique. What would be the sense of the mechanics? Those who do not fit, for some reason, in this gear, are left with the epithet of amusicals; that is, beings without a biological dowry" (p. 77) [2].

When it comes to practice we see these underlying issues in our society. Only the individual who is tuned is invited to join the choir; good musician is the one that can read the musical score, or can play "by ear"; all capabilities very focused on hearing conditions of those involved in the musical process and so the music concept vanishes without noticing the many other ways to listen to music around us and to understand that beyond the ear there are other possibilities of hearing it.

In contrast to this social representation, we have Schafer's vision of music where he says: "Music is an organization of sounds (rhythm, melody, etc.) with the intention to be heard." (p. 23) [3]. Still in Schafer, there are numerous accounts of how making music includes the use of sound objects found in a classroom.

The objective of the present work is to investigate how this experience takes place considering the culture of the deaf person. Thus, we began the present work on the musicality of the deaf, understanding that every being is musical and that the deaf person, seen in the light of historicalcultural perspective of Vygotsky, is an affectionintellect unity. The existence of the defect is a biological and not a limiting aspect of its development, being such difference, a human condition.

Thus, we realize that a musical education for the deaf person is possible and that this education should offer the same opportunities for experimentation and discovery in relation to the sound world that surrounds him a condition which is given to the hearing people.

\section{Deaf Culture}

When we are born, we are immersed in a culture and, over time, we become familiarized with, recognizing ourselves or not in and from it. This happens because we are cultural individuals. My behavior in society is a result of my cultural being. A quote from Laraia reinforces this view: "Man is the result of the cultural milieu in which he was socialized. He is the heir of a long cumulative process, which reflects the knowledge and experience gained by the many preceding generations"(p.45) [4].

Since culture is not the result of geographical or biological conditions, how can we define it? Still in Laraia we find that: ". . . taken in its broad ethnographic sense is this complex whole which includes knowledge, beliefs, art, morals, laws, customs or any other capacity or habits acquired by man as a member of a society" (Edward Tylor as cited in Laraia, p. 25) [4].

As mentioned above, culture is associated with the knowledge and habits of man within a society. But if culture bears within itself specific knowledge of a particular group, it is necessary to give attention to this group. In our present situation it is necessary to think of the deaf culture.

To understand the existence of a deaf culture within a single society triggers some questions: How does society perceive the deaf? How do they see themselves in society? How do they identify themselves? What does the history of the deaf people has to say about them and their culture?

In order to understand its present configuration, we must verify all these aspects because ". . . each culture follows its own path in the light of the different historical events it faced" (p. 36) [4].

Two facts of world renown illustrate the importance of recognition of a deaf person and the use of the sign language for this community.

In 1880 the International Congress of Deaf Educators (Milan), made up in its majority by listeners, positioned itself against the use of sign language. Instead, they established the oral instruction in the institutions, to the detriment of the gestural.

The second fact is associated with a university in the United the States dedicated to the education of deaf people.

The origin of Gallaudet University came about when Thomas Hopkins Gallaudet met a deaf girl named Alice Cogswe.

In the longing for a conversation, Thomas $\mathrm{H}$. Gallaudet decided to seek help and traveled to Europe, as he was aware of the existence of schools for the deaf. On this journey, in 1816, he met the deaf teacher, Laurent Clerc who was the auxiliary of Roch-Ambroise Cucurron Sicard, successor of the Abbot l'Epée.

Laurent Clerc agreed to go to the United States together with Thomas H. Gallaudet to open a school in the year 1817. The sign language used in the school had its origin in French sign language, since Laurent was a teacher now in that school, and received The name of American Sign Language ASL.

In the same vision of his father, Edward Miner Gallaudet, in 1857, founds in the United States the first university college for deaf people that later became the Gallaudet University, the only institution 
of higher education for deaf people, scene of the Revolution 1988.

As for the Abbe l'Epée, it is worth mentioning that he was known as the "father of the deaf" for allowing them to use sign language in France.

. . . L'Epée was impressed by the forms of communication he had observed with two deaf sisters. When asked to instruct them, he endeavored to learn from them. He offered them bread and obtained the sign of EAT; Water, and got the DRINK; Pointing to the surrounding objects, learned the names that applied to each of them (p. 107) [5].

In 1988 a movement took place at the Gallaudet University for deaf people in the United States. The movement, headed by students, staff and teachers became world known as the Gallaudet Revolution. It took over the scene where the voice of the deaf community of that school made itself heard demanding that their president and teachers be deaf.

After the revolution a new look was given to the deaf community of the whole world. Here is the story:

On Monday, March 6, there were rumors on campus that the board of directors of Gallaudet, made up of 17 listeners and 4 deaf, had chosen the new president among the three final candidates. Two of those candidates were deaf. . .

The only listener candidate, Dr. Elisabeth Zinser . . . knew very little about the deaf community and its culture. . . . The council proclaimed that Dr. Zinser was the new president. I saw the crowd react shocked, furious, incredulous, and in tears. Posters and leaflets were burned and speeches were made at ASL. The crowd thickened. ... The police tried to stop the march with megaphones, but the students did not respond to the warning. . . . The students presented four requirements to the council . . . first, the council had to withdraw the appointment of Dr. Zinser as president and replace it with a deaf president; Second, the president of the council had to resign; Third, membership of deaf members to the council was expected to reach 51 per cent; Fourth, there should be no reprisal against students who had protested (pp. 171-172) [5].

In Brazil, in 1857, in Rio de Janeiro, it was created the National Institute of Education of the Deaf - INES, the first establishment dedicated to the education of the deaf. For the first time this particular group could experience the sense of belonging when it comes to deaf people. Its foundation was possible because the professor Ernest Huet teacher of deaf and himself deaf, French, came recommended to the minister of France, Saint Georg and presented to the Marquis of Abrantes who decided to found the Imperial Institute of DeafMutes. Of French influence, the Institute adopted sign language as its means of communication among the deaf, although it was still considered a kind of mimicry that they used to communicate.

Only in 2002, through Law No 10. 436, of April 24, 2002, sign language was recognized as a Brazilian sign language - Língua Brasileira de Sinais (Libras) being considered the official means of communication of the deaf community.

This constant struggle to recognize himself as deaf has always been part of this movement of the deaf culture. To give meaning to existence in a context of equal and different; to become aware of its universe and his participation in it, because according to Gould, “. . . culture also influences what we see and the way we see" (p. 6) [6], and to think about deaf culture does not mean understanding the other from a viewpoint of segregation, but, as Skliar cited in Teske aptly states, ". . . of the existence of several cultural manifestations in the social relations" (p. 143) [7].

Thus, daily we become ourselves starting from the diverse cultural manifestations. Through oral communication, the child receives information about all the knowledge accumulated by the culture in which he (or she) lives [4], and therefore, through the sign communication, that is, through the use of sign language the deaf person becomes constitutes himself in his (or her) community.

This movement of the colletive/social dialogue with the individual allows to identify some deaf identities, and here we emphasize that, as dialectical movement these identities are not restricted to the definition of the five types of deaf identify proposed by Perlin, but are in constant development.

Deaf identities in Perlin are:

(1) Deaf identities: present in the group through which the deaf enter who makes use of the visual experience itself; (2) Deaf hybrid identities: deaf who were born listeners and with time become deaf; (3) Deaf transitional identities: deaf people who were kept under the captivity of the hegemonic listening experience that passed to the deaf community; (4) Incomplete deaf identities: represented by those deaf living under a listener ideology and (5) Floating deaf identities: deaf living and manifesting from the hegemony of listeners (pp. 63-66) [8].

Some literary sources justify the use of the expressions "deaf identities" and "deaf cultures" in the singular, with the sole objective of strengthening the group, because, they say, diversity is alive and present in our environment, a common trait of humanity.

All of these identities permeate the three most noticeable and common phases in the lives of deaf people and are based on three points: how identity is denied, how it is discovered, and how it is strengthened. 
Thinking about what Vygotsky spoke about the dialectic of the collective with the individual, we can see that the construction of these deaf identities basically occurs by this movement of the deaf person and his collective, in which the way he perceives himself within this collective constitutes it.

For some, the fact that they are deaf people has a sense of loss, since isolated from their culture they do not identify with the world around them and so, they prefer to take on the identity of hearing impaired - D.A to deaf people. Here is the account of one individual in this condition give by Rosa: "I am not deaf. I'm D.A.If I say that I'm deaf, I can not get what I want. I practice well. If I say that I am deaf, I do not have a good salary, a good job, or a girlfriend. I lose." -Uriel-. (p. 25) [9].

Here we see how important it is to "perceive" part of a group and, therefore, the sense of belonging is fundamental to guide life. With this we remember that the deaf culture has its own characteristics and a unique way of being common humanity, that is, what prevails is diversity. Diversity of cultural manifestations in everyday relationships.

Therefore, talking about music beyond the ear opens up a possibility of understanding with deaf people, as this process happens. Disconnecting music from the ear opens a new way, a new outlook on the hearing senses.

Conceiving the deaf person as a different nondisabled person enables a look at new ways of being and being in the world, which helps to understand this other form of musical experience of listening beyond the ear. ". . . the child whose development is complicated by the defect is not simply a child less developed than his normal contemporaries, but developed in another way" (p.12) [10].

Here, when mentioning the word defect, it is worth emphasizing that we speak of the biological condition of the person and also of the word chosen and used by Vigostki in his work Foundations of Defectology in which, when studying the development of people who had a different biological condition, concluded that they were no less than other people, who were not deficient in relation to others, but who were different.

Facing an impaired person, Vygotsky (1997) would not label, classify, diminish, exclude or segregate. He would make clear his position in defending that the development affected by this defect could not be considered, in relation to his pairs, an inferior development, but a development of his own, otherwise, in his own way.

The existence of the defect is not the problem but its consequence manifested in the social environment, since the prejudiced attitudes towards the defect of the other are presented within a standardized system for a normality.

Vigotski states that:
. . The culture of humanity is created under conditions of certain stability and consistency of the human biological type. That is why their material and adaptive tools, their devices and sociopsychological institutions are calculated for a normal psychophysiological organization. The use of these instruments and apparatus presupposes, as an obligatory premise, the existence of the intellect, the organs and the functions proper to man. The child 's attachment to civilization is conditioned by the creation of the corresponding functions and apparatus (p.27) [10].

It is worth noting that at that time there was no relation between the word defect and the sense of loss as it happens today; rather, it was a question of seeing the other as a person whose development occurred differently due to the biological defect, this circumstance not interfering in his human condition.

In this way, in Vygotsky, we perceive the individual in its entirety even before he presents any defect. We understand that every individual undergoes processes of compensation and adaptation finding in the defect the possibility of new paths for their development.

When we realize in Vygotsky's work that the defect becomes a deficiency in the heart of society, that is, a social construct, we can say that the human being often feels capable or not, in his society for his representation of him and the need to see oneself in the other for his own constitution as a person. I relate to myself how people relate to me. ". . . I am a social relation with myself" (p.8) [11].

The documentary "I'm Deaf and I Did not Know" [12] tells the story of Sandrine, a girl who is born deaf and who is slow to find herself deaf due to her lack of encounter with her neighbor. At school the character realizes that there are children who move their lips, but this does not make any sense to her. Sandrine realizes that she is not part of that universe, but also does not know to which universe she belongs.

Identifying with the other is at once simple and complex. On this constitution of the person, according to Arriens as cited in Rosa, "it is from the other, from the contact with the other deaf subject that the identity is discovered and strengthened. Such a deaf identity will only be constructed by the deafdeaf encounter" (p.22) [9]. This deaf identity belongs to a deaf culture here understood, according to Perlin and Reis, "as the emergence of the deaf, by means of sign language, deaf pedagogy (deaf way of teaching and learning), deaf arts, cultural history, identity, life and deafness experiences" (p.40) [13].

Vygotsky (1997) states that we become ourselves through others. Here we also see the importance of the dialectic of the individual being with his cultural milieu; of the dialectic between the social and the individual, where the collective forms the individual 
and in this movement they reciprocate. In the case of the deaf person, we see how much this representation interferes in his acceptance in the musical universe.

Society sees music as something belonging to the universe of listeners and this perception reflects in the life of the deaf person, in the way he (or she) perceives himself (or herself) or not participant in this universe, so the importance of understanding music as a possibility beyond the ear.

The fact that the deaf, apparently, does not perceive a musical being also has basis in this social reflection. Vygotsky already said: "Absolutely all the psychological peculiarities of the disabled child have in their base a nonbiological but social nucleus" (p. 81) [10].

After a brief knowledge about the deaf culture, about how it is perceived in the world and how it has been seen by society, the label of hearing deficiency that still impute to the deaf person the inability to develop certain activities, such as those related to music. Therefore, we are lead to believe that the absence of musical experiences most effectively for a long time in the deaf culture, was the fruit of the prejudiced society in which we are inserted and of the imposition of normatization on the world of the listener.

\section{Music, Musicality and Deafness}

The proposal presented here goes far beyond the social convention about music and how we can hear or interpret it. We deal here with the innumerable possibilities of meeting and perceiving the musicality in the deaf person's life from what he (or she) has to say about it.

The concept of music, in most cases, has been directly related to the elements of a conventional score or the learning of a specific musical instrument; that is, learning the sign, or technique. However, this is not the only way to understand music education and music.

In his book "The Thinking Ear," Schafer and his students, a long dialogue, come to the conclusion of what becomes music beyond the conventions we know:

Student: If I'm having dinner, the sound of cutlery slamming into the dishes is not music, but if I fill some glasses with water and percuss them, it becomes music. Right? Schafer: You answered. Intention makes the difference. . . . "music is organized sound". . . music is sound "with intent to be heard".

Student: Music is ... an organization of sounds ... with rhythm and melody ... with the intention of being heard.

Schafer: copying on the board. . . Music is an organization of sounds (rhythm, melody, etc.) with the intention of being heard (p. 23) [3].
In her dissertation, Pederiva pointed out that all beings are musical by reaching the conclusion that the sound production of the animals reveals the musicality of these. "Musicality exists in the animal kingdom. It is transformed by man into culture, in every musical activity" (p. 29) [2]. Musicality is not tied up to conventional music, "it is human behavior" [Pederiva, Personal communication, GEPPE- Group of Studies and Research in Educational Practice at the University of Brasilia] and it is about this musicality that we deal with throughout our work.

As we have a musicality that is transformed by man in his culture, we can consider that the expression and manifestation of this musicality in society also suffers this influence, this change; therefore, the way each person expresses and experiences it throughout his (or her) life. Life story is unique.

Similarly, the way in which music has come to be seen and lived in society has also undergone changes. "Music is not merely an evidence of our musical practices and meanings, but this evidence comes back to us through this ability to influence our beliefs, values, feelings and behaviors" (Green as cited in Pederiva \& Tunes. p. 116) [2].

Music has not been lived in its fullness, experienced in all its fullness. The rules and standards misrepresented its larger purpose, which was simply to live it in people's daily lives, as an expression of musicality. In this way it became an obligation for some, and for others, a tool for achieving something, deviating from the purpose of its essence: music by music itself, music as an expression of life.

In the meantime, musicality is deformed and disassociated from music and the human being. We have, thus, a teaching of music directed to few, the elected. It seeks perfection in the execution of notes based on the biological constitution of man, so that he (or she) is able to become an expert music professional. The deletion process is ready: “. . . many are excluded because they are too tall, too low, too fat, too thin, out of tune, because they do not know how to read music, because they only want to play in their churches or festivities" (p. 150) [2].

In this line of reasoning, musicality lost ground to a musical education with goals plastered in a cast and molded in professional training, in an unbridled search for perfection and excellence based on the quality standard and what is considered ideal in the musical field. One notes, therefore, and more and more the distancing of people who, faced with so many rules and norms, do not feel apt for their exercise and expression.

We emphasize that as an expression of life and life itself, before becoming institutionalized, music was accessible to all. It was the daily life of people, all of them expressed their musicality that was not dictated by norms and standards. 
The first contact with this sound universe is through our body. In our mother's womb we hear and perceive our heartbeat. We experience these sounds in a multifaceted way. Sometimes they are sounds that we produce, like our sobs, sometimes they are sounds produced by means external to us, like the breathing of our mother or the water falling on the floor when she takes a shower. The movements that we perform in that small space becomes sound. ". . . The representation of corporal movements expresses the musical phenomenon of rhythmic, melodic, harmonic character, phrases, structures and musical forms" (p. 25) [14].

The sound of the movement of the body experiencing in different ways, we feel in our skin, this is our musicality, that is, our creation, expression and musical interpretation. Therefore, according to Amorim "we have a body that is, at the same time, sound source and creative source for the expression of musicality" (p. 28) [15].

John Cage's experience, reported by Schafer, upon entering an anechoic chamber - that is, a completely soundproof room - in which he heard two sounds, a sharp and a bass one, and upon inquiring the responsible engineer, was surprised by his response, that "acute was my own nervous system in operation, and the bass was my blood circulating" (p. 118) [3].

Therefore, all these sounds, according to Schafer (2011) have timbre - the color of the sound; amplitude - strong and weak (by amplitude it is possible to conclude that the sound moves); melody any combination of sounds; texture - the counterpoint and rhythm - that is the direction of sound - and can constitute a musical sensation, as it is experienced by each and every individual.

The clapping, the humming, the snapping of fingers, all these are other possibilities of making music from the body itself [15] or object of sound in a conscious act of musical creation and that does not necessarily require a conventional instrument to perform, as exemplified by Schafer:

Schafer: Have you ever thought of a piece of paper as a mechanism to produce sound?

Student: No, not exactly.

Schafer: Here's an opportunity. Each one take your sheet of paper and try to make a sound with it. How many different ways will we find to produce sounds? (p. 92) [11].

This whole process is part of what we think and propose when we think about musical education, as a development of a musicality belonging to all. Musical education, then, is not based on the professionalization of the children, but the promotion of musical educational activities aimed at the development of their musicalities aiming at the recognition, exploration and creation of the sound world. And for the technical learning of a specific instrument, for the teaching of music, according to Schafer, traditional:

Teaching in traditional music has its special objectives: the technical mastery of instruments such as the piano, trumpet, or violin for the execution of a literature spanning several hundred years. In order to understand the forms of this music, a theoretical vocabulary has been developed that enables the student to perform, in a seemingly acceptable way, any work of Western music written between the Renaissance and our own epoch (pp. 109-110) [3].

The sign language itself, being a visual-gestural language, presents its musicality. It is not a language of "silence." It reflects a non-verbal, sensitive, visual, and sonic aspect. The Portuguese language has sound, melody, rhythm, timbre, and we listeners, we listen to it. Similarly, deaf people talk and listen, for sign language - LS - is not silent.

Caldas shows us these sonic aspects of sign language which, in his view, has seven characteristics:

Rhythm: According to the rhythm imposed by the LS user during its use, we can "hear" the cadence of the LS. The signals expressed in sequence, which shows its rhythm; Movement: the movement of the signals during the use of the LS allows us to evidence its movement. From top to bottom; about; upwards; Diagonally; In contact with the body; or without body contact; Rhyme: evidenced mainly by the use of hand configurations (HCs), rhyme is the main mark of poetry, in which from a $\mathrm{HC}$ or a set of them an aesthetic text is created; Body and facial expressions: This feature is one that I find harder to think about in terms of verbal or nonverbal aspects separately. It is she who presents the emotion, the feeling, the poetry of the LS, being related to the signal executed. Example: The sign of sad must be accompanied by the expression of sad; Iconicity: signs in which the shapes of real objects are perceptible. Its aesthetic mark is evidenced when in harmony with the movement; Intensity: is related to movement. We can think of a fast or slow movement with a strong or weak intensity. Thinking about the sound of LS intensity as a sea metaphor, I compare it to waves that can be strong, weak, vibrant, large, small; Position: Your sound mark can be highlighted at times of storytelling, when a narrator takes the place of another character, his position during the execution of the signs will mark the way of each character, including his voice. Thus, his relation with the expression is very important, because when he takes on the role of the wolf and the little pigs, his expression will be accompanying the position to highlight the characters (p. 141) [16]. 
Corroborating with what Caldas said about the sonority of sign language, it is worth mentioning Schafer's speech about the relation of movement and sound: "Anything that moves in our world vibrates the air. If it moves so that it oscillates more than sixteen times per second, this movement is heard as sound. The world, then, is full of sounds. Listen, then" (p.112) [3].

The omnipresence of musicality, referred to previously, is also highlighted by Pederiva (2013) who construes it as human behavior, experienced also by our corporeity. We see here that the deaf person has, from the mechanism of his communication, his language, which is gestural, the experience of this musicality even though still unconsciously, for in Schafer we have to:

... the regular movements producing the musical sounds were accurately investigated by physicists. They are oscillations, vibrations or swings, that is, movement of sound bodies up and down or back and forth, and it is necessary that these oscillations have regular periodicity ( $p$. 124) [3].

Thus we perceive that just as the listener listens to words spoken by ourselves and others, the deaf person also "listens" to the sound of the signaled words because, according to Schafer, "the sensation of a musical sound is due to the rapid and periodical movement of a sonorous matter" (p. 124) [3].

Beyond the physical make up of sound, Gesser calls the attention to the cultural environment in which it is embeded, particularly, the mother tongue: "sounds extrapolate their physical-acoustic characteristics and acquire culturally related meanings" (p.48) [17]. Consequently, she makes explicit that there are different ways of perceiving and experiencing sound.

Similarly, the living and musical experience of deaf people can also be experienced from body movement, dance, feeling, perceiving and "listening" through the "ear" and by means of the movement and body of the other.

Gesser, relates an embarrassing experience in the field of the deaf person's experiences when asked by a deaf student at Gallaudet University in the United States about how samba was performed. Caught by surprise, she said she could not show it to him because she did not have the music there. Here is his account:

... So he told me to close my eyes and imagine the music. Imagine the music? As well? Of course, I should resort to my acoustic memory ... I felt a very big limitation and I saw how much I depend on the sound of music to dance. Talk goes, talk comes, a deaf took me out to dance. I was embarrassed. There was music in the room, but because I knew I was deaf and did not listen, I biasedly thought he would not be able to keep up with the music. [...] experiencing with them this situation I built my understanding of how they conceive of music and rhythm: through vibration, through observation of the movement of other individuals, through bodily contact with someone who guides the rhythm, and thus onwards. Like us, listeners, the deaf distinguishes rhythms and musical genres (p.49) [17].

The world is full of music and movement, which can be seen within the various cultures, where music is used at all times, during celebrations, rituals; in the expressions of joy and sorrow, in short, music is something of the universe itself. All these things the deaf can see and perceive. The waves of the sea, the birds, the wind...

The deaf reacts to music expressing musicality; in other word, the deaf has manners of listening, perceiving, and feeling music. This possibility of the deaf is expressed in the following citation:

$[\ldots]$ The whole body can pick up the vibrations of sound waves. These can be perceived by the skin and the bones. The skin is the body's most vital sense. One can live without hearing, sight, smell, taste, but it is impossible to live without the skin. The skin defines the limits of the body, providing its relationship with the outside world. Therefore, it is a fundamental means of communication with each other. It serves as a general broadcast channel. It follows that the sounds may affect the subject. Also, benefiting from it, the deaf subject can then take advantage of this sound world and react to it (p. 79) [18].

An interesting report we also find in Schafer when he states that several parts of our body resonate at different frequencies and, accordingly, he presents to his students the following discourse:

... You know the experience in which a very deep pedal note played In the organ, makes the whole church vibrate. Possibly, one can imagine a type of massage music, resulting from very deep frequencies, since it is the area in which the sense of hearing and the sense of touch overlap. I met some young composers who were interested in this world of musical massage, and they claim to have composed pieces that used only those deep frequencies (p. 145) [3].

\section{Sensory Ethnography}

When we propose to perceive music beyond the ear, in a musical development context of deaf people, considering their culture, in a historical-cultural perspective, we are reminded of its due importance, as Sa stresses:

[...] Many approaches give the impression that one is forcing the deaf to participate in something that disregard deaf cultural marks, giving the impression that one is forcing the deaf to participate in something that does not take into account their biological characteristics which 
threatens their identity, which does not consider the deaf culture and that is an imposition of listeners [19].

Sensorial ethnography meets the principle of unity of affect-intellect functioning in human behavior. This principle dialogues with the historical-cultural perspective, which presents and understands the unity of the intellect-affective experiences of each person as a unique integral process and that by entering the culture of the other we learn with him and from him. With Vygotsky we have to conclude that: "the knowledge that does not pass through personal experience is not knowing" (p.76) [10], hence the choice by ethnography.

Sensory Ethnography, proposed by Pink [20], directs us to an ethnography based on the perceptual unity of the human being, beyond what has been commonly treated, used and analyzed in the research. Understanding the individual in the entirety of his senses, taking Vygotsky's intellect-affect unit as a compass, we can probe new sensory categories, be they related to any of our senses.

\section{Conclusion}

It is therefore important to think about the importance of understanding, understanding and glimpsing musicality from another angle, by realizing that every individual is a musical being, full of musicality. Assuming that music is not perceived and lived only by the heard and even that music restricts itself to the scores, notations and other formalities, but that it is lived daily in different ways and by different perceptual ways, in the totality of the being, in consonance with the reality that we are all musical beings and possibilities.

It is possible to think that music has not always been experienced and experienced as we see in the present day where there is a pattern for the beautiful, for the acceptable, for the normal. Music simply existed and it was given to each person to experience it and experience it in their own way.

In Pederiva and Tunes (2013) we saw that the transmission of music took place through generations and were guarded zealously in the context of tribes, for example, by sorcerers. In this context neither tuning or untunig existed. Everyone's musicality was part of everyday life.

What society needs to understand is the complexity of each individual's unique development, considering the human diversity, the environment in which they live, the experiences that live together in an educational social environment. This environment refers to the organization of society capable of providing and making available to its individuals all the necessary tools for his (or her) full development, within his (or her) potentialities and not his (or her) limitations.
In this way, we contemplate the possibility of creating paths, together with the deaf culture, of living the musicality stripped of all prejudices, burdens and moorings which impregnates society when it comes to music and, especially, when dealing with the development of musicality of the deaf person. We envision an education that seeks to discover which pedagogical practices in the teaching of music facilitates the musicalization of the deaf people, their global development and their participation in society, whether in the school environment or in music schools without treating music as a function of Education, and with an end in the development of the musicality of the person.

In order to approach the universe of the deaf culture, we conducted a pilot study during the first semester of 2016, whose objective was, in addition to this approach, the initial understanding of the ways in which the deaf person expresses his (or her) musicality, thus corroborating the proposed methodological approach. Since as Magnani says:

. . . ethnography is a special way of operating in which the researcher comes into contact with the universe of the researched population and shares their horizon, not to remain there or even attest to the logic of his world view, but to follow them as far as possible in a true exchange relationship, to compare their own theories with theirs and thus try to come out with a new model of understanding or, at least, with a new clue not previously predicted (p.135) [21].

First, we visited a music school with the intention of finding, in this universe, some deaf people. We wanted to understand, in an initial way, what their relationship with their musicality would look like. In a second moment, we visited the percussion group Surdodum, formed by deaf members and listeners. And in a third moment we talked with two deaf people.

The pilot project was the first approximation with some participants of the research, where we began to draw the lines of the innumerable possibilities of listening beyond the organ of hearing, the ear, conceiving the human being in its unity, considering the functioning of the organism in a globalized way.

We then took the opportunity to raise the question of how they related to music. Afterwards we bring some results of the accomplished pilot.

On a visit to a music school, we learned that there were only three deaf students: one, a seventeen year old girl and two boys between eight and thirteen years old. All were deaf with partial losses and had other deficiency diagnoses, according to information from the head of the school. They did not use sign language and were oralized. We could not contact them because it was class council day and the class was dismissed.

In a conversation with the person responsible for the information, we realized that since it was a 
school of music, the focus of the institution was not to perceive how the musical expression of deaf people occurs, but rather, the learning of some specific instrument. That is, the technique and skills in each instrument, in the execution of the same. The seventeen year old girl was on the drums and the boys were in the childrens' music class.

These three students were also attended by a nucleus of inclusion for the purpose of talking and verifying the learning increment of each one during the course.

We left that place disappointed because there was an expectation that there would be some young or even deaf adults with whom we could talk about their musicality.

Our expectation was the direct contact with the people of the deaf culture. So we wondered why these deaf people did not and enrol in a music school; that is, why there were not more deaf student in that music school? Was it because of an inadequate proposal that they did not consider their unique ways of experiencing their musicalities, or was it because they did not feel like "listeners" and part of this sound universe? Was it because of lack of opportunity, other ways of perceiving them as musical beings? Was it because of the absence of a Libras professional?

Our second moment of the pilot project was the visit to the Surdodum group. It was their day of rehearsal. In conversation with a deaf person, that is, the person who has a hearing loss above 91 decibels, he said he enjoyed listening to music and dancing. His walks around the Guará, an Administrative Region of Brasilia, are made with headphones and music playing. In his account he said that people look and think he listens, but he tells me that he does not hear anything.

Another episode that he told us relates to the context of a party. Usually, he stands next to the sound box to feel the pulse of the music. He was dancing on the dance floor when a woman approached and began to talk. To her surprise, he said he was deaf. As she knew Libras, they began a conversation and she said that she was impressed how well he danced.

Thus we see a way of experiencing the musicality of this profound deaf person. We can once again demonstrate that deaf people have ways of expressing, in their own way, their musicality.

In continuation of the pilot project and as example of this research, fruit of conversations with deaf people that somehow begin to trace the lines of the many possibilities of what is heard beyond the ear. In conversation with a deaf person, she recounts her musical experience of feeling the vibration of the music when a balloon at a party falls into her hand. Afterwards, she already in possession of the balloon, begins to dance and enjoy that musical moment, listening through the vibrations that his touch could capture while touching the balloon.

She can experience her musicality through other perceptible paths. Gibson, as cited in Ingold, tells us that "Perception is the realization not of a mind in a body, but of the whole organism as it traverses its environment, and that what it perceives are not things as such, but what they offer for the pursuit of its activity" (p. 37) [22].

Here is a new way to listen to music through another sense, which supports the use of sensory ethnography, whose experiences are always multisensory.

In a new conversation with another deaf person, the musical experience in turn leads us to the observation of the body movement of the other person. She reports that her sister, who was listening to music, began to dance, rocking her body; meanwhile, she watched those movements and mimicked them, dancing too. The same happened when going out to parties with friends.

Vygotsky speaks of the importance of the repetition or reproduction of means of conduct in the activity of man where the experience of the other also constitutes us:

It is easy to understand the enormous meaning of

the conservation of the previous experience for the life of man; how much it facilitates its adaptation to the world that surrounds it, in creating and elaborating permanent habits that are repeated in equal conditions (p. 12) [11].

Note here that the observation of those movements and the mimic of them allowed her to listen to music; again, this hearing was possible despite the hearing. It was carried out by the interconnectivity of the senses, where the look and touch enabled hearing.

Therefore, it is expected by means of the present study, to contribute to the expansion of the experiences of these people in the domain of education, as well as to propose new standards that may enhance the theoretical and philosophical perspectives of it and also the practice on the subject.

\section{References}

[1] Tunes, E. Bartholo, R. (2008). O Trabalho Pedagógico na Escola Inclusiva. In: TACCA. M.C.V.R. (org). Aprendizagem e trabalho pedagógico. Campinas, SP: Ed. Alínea.

[2] Pederiva, P. L. M. \& Tunes, E. (2013). Da Atividade Musical e sua Expressão Psicológica. Editora Prismas, Curitiba/Brasil, 2013.

[3] Schafer, M. (2011). O ouvido pensante. Ed. Unesp, São Paulo/Brasil.

[4] Laraia, R. de B. (2014). Cultura: um conceito antropológico. Rio de Janeiro: Zahar. 
[5] Lane, H. (1992). A máscara da benevolência: A comunidade surda amordaçada. Horizontes Pedagógicos. Instituto Piaget. Lisboa.

[6] Gould, S. J. (2014). A falsa medida do homem. 3. ed. São Paulo. WMF Martins Fontes.

[7] Teske, O. (2015) A relação dialógica como pressuposto na aceitação das diferenças: o processo de formação das comunidades surdas. In SKLIAR Carlos (org). A surdez: Um olhar sobre as diferenças. $7^{\mathrm{a}}$ ed. Porto Alegre: Medicação.

[8] Perlin, G. T.T. (2015). Identidades Surdas. In SKLIAR Carlos (org). A surdez: Um olhar sobre as diferenças. $7^{\text {a }}$ ed. Porto Alegre: Medicação.

[9] ROSA, E. F. (2012). Identidades Surdas: o identificar do surdo na sociedade. In: PERLIN, Gladis; STUMPF, Marianne (orgs.). Um olhar sobre nós surdos. Leituras contemporâneas. 1 ed. Curitiba, PR: CRV.

[10] Vigotski, L. S. (1997) Obras Escogidas V: Fundamentos de Defectología. Aprendizaje Visor, Madrid/Espanha.

[11] Vigotski, L S. (2009). Imaginação e criação na infância: ensaio psicológico - livro para professores. Tradução de Zoia Prestes. São Paulo: Ática.

[12] OCHRONOWICZ, Igor. 2009. I'm Deaf and I Did not Know. Documentário Disponível em: https://www.youtube.com/watch?v=Vw364_Oi4xc> (Access Date: 2 February, 2017)

[13] PERLIN, Gladis \& REIS, Flaviane. (2012). SURDOS: cultura e transformação contemporânea. In: PERLIN, Gladis; STUMPF, Marianne (orgs.). Um olhar sobre nós surdos. Leituras contemporâneas. 1 ed. Curitiba, PR: CRV.

[14] Pederiva, P. L. M. 2006. O corpo no processo ensino aprendizagem de instrumentos musicais: percepção de professores. Dissertação de mestrado. Universidade Católica de Brasília. Disponível em: https://bdtd.ucb.br:8443/jspui/bitstream/123456789/816/1/ Patricia\%20Pederiva.pdf. (Access Date: 2 February, 2017)

[15] Amorim, R. R. S. 2016. Batucadeiros: Educação musical por meio da percussão corporal. Dissertação de Mestrado. Faculdade de Educação, Universidade de Brasília-UnB. Disponível em: http://repositorio.unb.br/handle/10482/20165. (Access Date: 2 February, 2017)

[16] Caldas, A. L. P. (2012). A língua de sinais e os sons: uma apreciação estética. In: Beyer, E.; Kebach, P. (orgs.). Pedagogia da música: experiências de apreciação musical. 2 ed. Porto Alegre: Mediação.

[17] Gesser, A. (2015). Libras? Que língua é essa?: Crenças e preconceitos em torno da língua de sinais e da realidade surda. São Paulo: Parábola Editorial.

[18] Haguiara-Cervellini, N. (2003). A musicalidade do surdo: representação e estigma. Plexus Editora, São Paulo/Brasil.
[19] Sá, N. R. L. 2008. Os surdos, a música e a educação. Dialógica - Revista Eletrônica da FACED - Faculdade de Educação da Universidade Federal do Amazonas. [Online]. vol.2, n.5. Disponível em: http://dialogica.ufam.edu.br/dial ogicaV2-N5.html. (Access Date: 2 February, 2017)

[20] Pink, S. (2015). Doing sensory ethnography. Sage, London.

[21] Magnani, J. G. C. (2009). Etnografia como prática e experiência. Horizontes Antropológicos, Porto Alegre, ano 15 , n. 32, p. 129-156, jul./dez. Disponível em: http://dx.doi.org/10.1590/S0104-71832009000200006. (Access Date: 2 February, 2017)

[22] Ingold, T. (2015) Estar vivo: ensaios sobre movimento, conhecimento e descrição. Petrópolis, RJ. Ed. Vozes. 